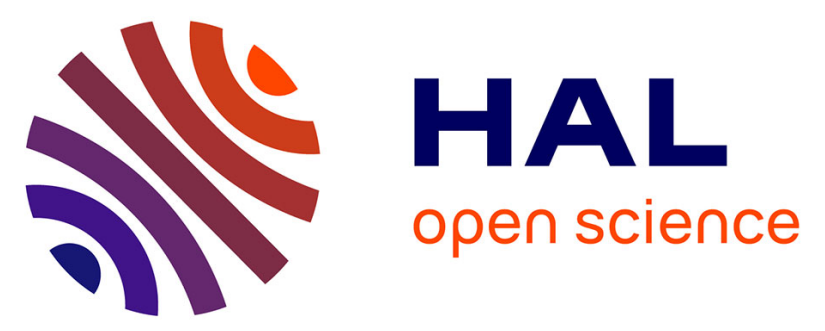

\title{
1- and 2-Photon Phototherapeutic Effects of Ru(II) Polypyridine Complexes in the Hypoxic Centre of Large Multicellular Tumour Spheroids and Tumour-Bearing Mice
}

Johannes Karges, Shi Kuang, Yih Ching Ong, Hui Chao, Gilles Gasser

\section{To cite this version:}

Johannes Karges, Shi Kuang, Yih Ching Ong, Hui Chao, Gilles Gasser. 1- and 2-Photon Phototherapeutic Effects of $\mathrm{Ru}(\mathrm{II})$ Polypyridine Complexes in the Hypoxic Centre of Large Multicellular Tumour Spheroids and Tumour-Bearing Mice. Chemistry - A European Journal, 2020, 10.1002/chem.202003486 . hal-02971792

\author{
HAL Id: hal-02971792 \\ https://hal.science/hal-02971792
}

Submitted on 19 Oct 2020

HAL is a multi-disciplinary open access archive for the deposit and dissemination of scientific research documents, whether they are published or not. The documents may come from teaching and research institutions in France or abroad, or from public or private research centers.
L'archive ouverte pluridisciplinaire HAL, est destinée au dépôt et à la diffusion de documents scientifiques de niveau recherche, publiés ou non, émanant des établissements d'enseignement et de recherche français ou étrangers, des laboratoires publics ou privés. 


\section{1- and 2-Photon Phototherapeutic Effects of Ru(II) Polypyridine Complexes in the Hypoxic Centre of Large Multicellular Tumour Spheroids and Tumour-Bearing Mice}

Johannes Karges, ${ }^{[\mathrm{a}]}$ Shi Kuang, ${ }^{[\mathrm{b}]}$ Yih Ching Ong,${ }^{[\mathrm{a}]}$ Hui Chao, ${ }^{*[\mathrm{~b}]}$ and Gilles Gasser*[a]

a Chimie ParisTech, PSL University, CNRS, Institute of Chemistry for Life and Health Sciences, Laboratory for Inorganic Chemical Biology, 75005 Paris, France.

b MOE Key Laboratory of Bioinorganic and Synthetic Chemistry, School of Chemistry, Sun Yat-sen University, 510275 Guangzhou, People's Republic of China.

*Email: $\quad$ ceschh@mail.sysu.edu.cn, $\quad$ Tel. $\quad+86 \quad 20 \quad 84110613$, Email: $\begin{array}{lllllllll}\text { gilles.gasser@chimieparistech.psl.eu; } & \text { Tel. } & +33 & 1 & 44 & 27 & 56 & 02 ; & \text { WWW: }\end{array}$ www.gassergroup.com.

ORCID-ID:

Johannes Karges: 0000-0001-5258-0260

Hui Chao: 0000-0003-4153-5303

Gilles Gasser: 0000-0002-4244-5097

Keywords: Bioinorganic Chemistry • Medicinal Inorganic Chemistry • Metals in Medicine • Photodynamic Therapy • Photosensitizers 


\begin{abstract}
:
During the last decades, photodynamic therapy (PDT), an approved medical technique, has received increasing attention to treat certain types of cancer. Despite recent improvements, the treatment of large tumors remains a major clinical challenge due to the low ability of the photosensitizer (PS) to penetrate a 3D cellular architecture and the low oxygen concentrations present in the tumour centre. To mimic the conditions found in clinical tumors, exceptionally large 3D multicellular tumour spheroids (MCTSs) with a diameter of $800 \mu \mathrm{m}$ were used in this work to test a series of new $\mathrm{Ru}(\mathrm{II})$ polypyridine complexes as 1-Photon and 2-Photon PSs. These metal complexes were found to fully penetrate the 3D cellular architecture and to generate singlet oxygen in the hypoxic centre upon light irradiation. While having no observed dark toxicity, the lead compound of this study showed an impressive phototoxicity upon clinically relevant 1-Photon $(595 \mathrm{~nm})$ or 2-Photon $(800 \mathrm{~nm})$ excitation with a full eradication of the hypoxic centre of the MCTSs. Importantly, this efficacy was also demonstrated on mice bearing an adenocarcinomic human alveolar basal epithelial tumour.
\end{abstract}




\section{INTRODUCTION}

Cancer has emerged as one of the deadliest diseases worldwide. Photodynamic Therapy (PDT) is a minimal invasive medical technique to treat this disease, often in combination with other methods (i.e., surgery, chemotherapy, radiation therapy or immunotherapy). In PDT, a preferably non-toxic photosensitizer (PS) is activated at a specific wavelength to generate reactive oxygen species (ROS). The majority of clinically approved PSs act by an energy transfer of the PS to molecular oxygen $\left({ }^{3} \mathrm{O}_{2}\right)$ to generate singlet oxygen $\left({ }^{1} \mathrm{O}_{2}\right)$. As ROS and ${ }^{1} \mathrm{O}_{2}$ are highly reactive, they can rapidly interact with their biological surroundings to trigger cell death. ${ }^{[1]}$ Despite recent research advances, the clinical applications of PDT remains sometimes unsatisfactory. Many tumours and especially large tumours show, after a PDT treatment, a regression of their outer spheres while their core remain intact, causing, after a certain time, a cancer relapse. ${ }^{[2]}$ This incomplete tumour eradication is due to several factors: 1) the PS is not able to penetrate a 3D cellular architecture; 2) the oxygen concentration in the centre of the tumour is low (i.e., hypoxia), which is hampering the production of the therapeutically necessary ROS and ${ }^{1} \mathrm{O}_{2}$; 3) light is not delivered to the tumour centre. ${ }^{[3]}$ Consequently, there is a need for the evaluation of new PSs in large tumour models that can better simulate the conditions found in the tumours of patients.

Multicellular tumour spheroids (MCTSs) can mimic the pathological conditions found in clinically-relevant tumours. MCTSs with a diameter of $200 \mu \mathrm{m}$ are frequently used to simulate 3D cell-cell as well as cell-matrix interactions. They can therefore be utilised to model the drug delivery of a compound. ${ }^{[4]}$ This is important since many investigated drug candidates have failed the translation from promising results in a $2 \mathrm{D}$ monolayer model to a $3 \mathrm{D}$ or an in vivo model due to compromised drug delivery. ${ }^{[5]}$ Furthermore, MCTSs are also able to simulate hypoxia and proliferation gradients to the centre. Since the vast majority of PDT agents act by an oxygen-dependent mechanism, the treatment of hypoxic tumors remains a major medical challenge. ${ }^{[6]}$ Despite these limitations, the successful treatment of the hypoxic regions of melanoma MCTSs with a diameter of $280 \mu \mathrm{m}$ was recently reported. ${ }^{[7]}$ Studies have shown that the oxygen diffusion inside of MCTSs is limited to approximately $200 \mu \mathrm{m} .{ }^{[8]}$ Therefore, larger MCTS are able to generate a hypoxic core, which can better simulate the pathological conditions found in clinically-relevant tumours. Despite these benefits, studies of the antitumor effects of compounds in large MCTSs remain very rare. ${ }^{[9]}$ To overcome this limitation and promote a better understanding of the biological effects of new compounds, there is an urgent need for in-depth studies of the ability of new compounds in large MCTSs. 
$\mathrm{Ru}(\mathrm{II})$ polypyridine complexes are gaining increasing attention as PDT PSs due to their attractive chemical and photophysical properties (e.g., high water solubility, chemical stability and photostability). ${ }^{[10]}$ Despite their remarkable characteristics, the majority of PSs are activated using either UV or blue light, limiting the light penetration inside the tissue and therefore their application to treat deep seated or large tumours. To overcome this limitation, there is a need for the development of $\mathrm{Ru}(\mathrm{II})$ polypyridine complexes with an absorption in the biological spectral window $(600-900 \mathrm{~nm}) .{ }^{[11]}$ This aim could be achieved by a red-shift of the 1-Photon (1P) absorption or the use of a 2-Photon (2P) process, in which the compound absorbs two photons of low energy/high wavelengths simultaneously. Next to a deeper tissue penetration, a $2 \mathrm{P}$ excitation correlates with a reduced photodamage as well as enhanced spatial resolution. However, the $\mathrm{Ru}(\mathrm{II})$ polypyridine complexes reported so far were found to have relatively poor $2 \mathrm{P}$ photophysical properties ${ }^{[7,9 a, 12]}$ compared to porphyrins, porphyrin oligomers or expanded porphyrinoids, ${ }^{[13]}$ limiting the application of this technique with these complexes. In this context, we have recently reported the rational design of the complexes $\left[\mathrm{Ru}(\text { bipy })_{\mathrm{n}}\left(\mathrm{L}-\mathrm{NMe}_{2} / \mathrm{L}-\mathrm{OMe}\right)_{3-\mathrm{n}}\right]^{2+}$ (bipy $=2,2^{\prime}$-bipyridine, $\mathrm{L}-\mathrm{NMe}_{2}=\left(E, E^{\prime}\right)-4,4^{\prime}$-bis $[p-(N, N-$ dimethylamino)styryl $]-2,2^{\prime}$-bipyridine, $\quad$ L-OMe $=\left(E, E^{\prime}\right)-4,4^{\prime}$-bis[ $p$-methoxystyryl $]-2,2^{\prime}$ bipyridine, $\mathrm{n}=0,1,2$, Figure 1) as effective PSs for 1P (540 nm) and 2P (800 nm) PDT. ${ }^{[14]}$ Worthy of note, the use of $\left(E, E^{\prime}\right)-4,4^{\prime}$-bisstyryl-2,2'-bipyridine type $\mathrm{Ru}(\mathrm{II})$ polypyridine complexes were previously reported as effective $2 \mathrm{P}$ absorbing chromophores. ${ }^{[15]}$ The lead compound of our study, namely $\left[\mathrm{Ru}(\text { bipy })_{2}(\mathrm{~L}-\mathrm{OMe})\right]^{2+}$ was found to be active in vivo. ${ }^{[14]}$ Despite the impressive biological property of this complex, its lack of $1 \mathrm{P}$ absorption in the biological spectral window and poor $2 \mathrm{P}$ absorption is limiting the application for deep-seated or large tumors.

With this in mind, in this work, the analogous complexes that bear different ancillary ligands $\left[\mathrm{Ru}(\text { phen/bphen })_{2}\left(\mathrm{~L}-\mathrm{NMe}_{2} / \mathrm{L}-\mathrm{OMe}\right)\right]^{2+}(\mathbf{1 - 4}$, phen $=1,10$-phenenthroline, bphen $=4,7-$ diphenyl-1,10-phenanthroline) are reported as effective PSs. The lead compound of this new study was found to have a red-shifted $1 \mathrm{P}$ and strong $2 \mathrm{P}$ absorption, enabling a phototherapeutic effect upon 1P $(595 \mathrm{~nm})$ or 2P $(800 \mathrm{~nm})$ excitation. An in-depth analysis of their ability to treat the hypoxic core in extraordinary large MCTS is presented. Further this complex was found to eradicate an adenocarcinomic human alveolar basal epithelial tumour inside a mouse model. 
Previously studied compounds:
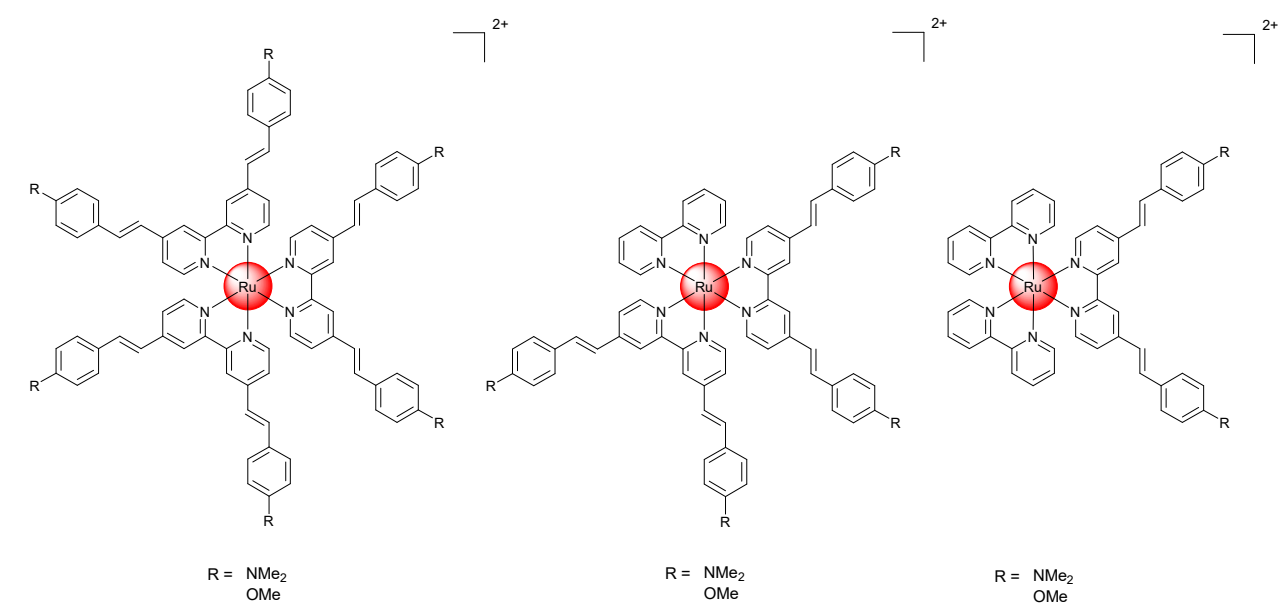

New compounds:
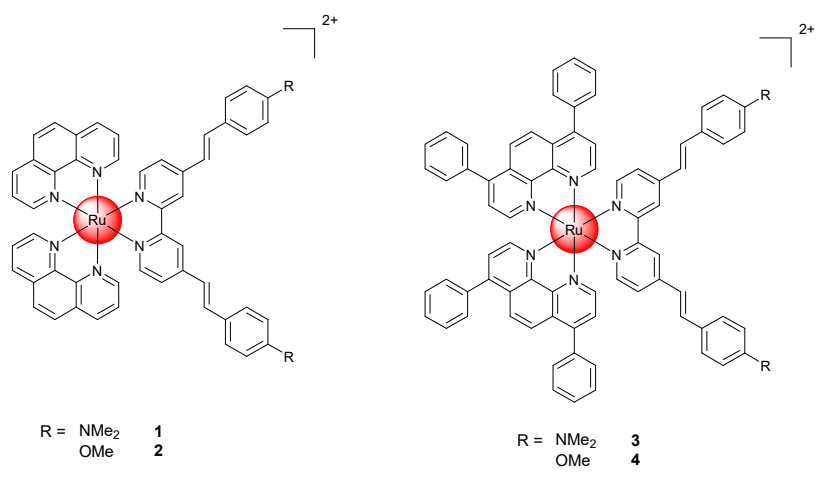

Figure 1. Chemical structures of previously studied and new compounds investigated in this work. The followed letter a corresponds to the compounds as a hexafluorophosphate salt whereas the letter $\mathbf{b}$ indicated the compound as a chloride salt. 


\section{RESULTS AND DISCUSSION}

To the best of our knowledge, the synthesis of the complexes 1-4 (Figure 1) has not been reported yet. The ligands $\mathrm{L}-\mathrm{NMe}_{2}$ and L-OMe were synthesized as previously reported by our group. ${ }^{[14]}$ The precursors $\mathrm{Ru}(\text { phen })_{2} \mathrm{Cl}_{2}$ and $\mathrm{Ru}$ (bphen) ${ }_{2} \mathrm{Cl}_{2}$ were prepared as described in the literature. ${ }^{[16]}$ Finally, the chloride substituents of the respective precursors were substituted with $\mathrm{L}-\mathrm{NMe}_{2}$ or L-OMe, yielding the desired complexes 1a-4a. All compounds were characterized using ${ }^{1} \mathrm{H}-,{ }^{13} \mathrm{C}-\mathrm{NMR}$, HR-MS analysis and the purity of the compounds verified by HPLC and elemental analysis. Details on the synthesis and characterization of the complexes can be found in the SI (Scheme S1-S2, Figure S1-S12).

To evaluate the potential of the compounds, their photophysical properties (Table S1) were determined. All complexes were found to have a strong red-shifted 1P absorption as indicated by their high extinction coefficients and absorption tail towards longer wavelengths (Figure S13a). Strikingly, the complexes have an exceptionally high $2 \mathrm{P}$ absorption up to $\sim 1600 \mathrm{GM}$ (Figure S13b), which is an order of magnitude higher than the majority of previously reported $\mathrm{Ru}(\mathrm{II})$ polypyridine complexes ( 40-250 GM). ${ }^{[7,9 \mathrm{a}, 12]}$ Importantly, the compounds have a $1 \mathrm{P}$ absorption tail towards and $2 \mathrm{P}$ absorption within the biological spectral window (600-900 $\mathrm{nm}$ ), potentially allowing them to be utilized for the treatment of deep-seated or large tumours. The maximum of the emission of the complexes (Figure S14) was determined to be at $698 \mathrm{~nm}$ for the L-NMe - -coordinated complexes (1a, 3a) and at $663 \mathrm{~nm}$ for the L-OMecoordinated complexes (2a, 4a), resulting in a large Stokes shift for all investigated compounds. The comparison of the excitation and absorption spectra of all compounds showed no significant differences. The L-NMe 2 or L-OMe ligands play a significant role in the absorption and emission characteristics of the complexes since complexes $\mathbf{1}$ and $\mathbf{3}$ as well as $\mathbf{2 a}$ and $4 \mathbf{a}$ have similar absorption and emission profiles. The analysis of the excited states of the analogous bipy derivatives suggested that these transitions stem from metal-to-ligand charge transfer/ligand-to-metal charge transfer excitations. ${ }^{[14]}$ The comparison between the complexes revealed that the L-OMe-coordinated analogous (2a: $1.9 \%$, 4a: $2.7 \%$ ) have a significantly higher luminescence quantum yield than the $\mathrm{L}-\mathrm{NMe}_{2}$-coordinated compounds (1a: $0.4 \%$, 3a: $0.6 \%$ ). Worthy of note, other previously published Ru(II) polypyridine complexes with terminal dimethylamine groups were also found to be poorly luminescent. ${ }^{[11 \mathrm{c} \text {, }}$ ${ }^{23 d]}$ Theoretical calculations for the $\left[\mathrm{Ru}(\mathrm{bphen})_{2}\left(\left(E, E^{\prime}\right)-4,4^{\prime}\right.\right.$-bis $\left(N, N^{\prime}\right.$-dimethylaminovinyl)$2,2^{\prime}$-bipyridine $\left.)\right]^{2+}$ complex indicated that the energetically lowest lying excitations are based on non-luminescent ligand-centred transitions. ${ }^{[23 \mathrm{~d}]}$ The bphen coordinated compounds (3a, 
4a) showed a stronger luminescence than the phen coordinated compounds (1a, 2a). This observation is in agreement with the comparison between the corresponding parent complexes $\left[\mathrm{Ru}(\mathrm{phen})_{3}\right]^{2+}$ and $\left[\mathrm{Ru}(\mathrm{bphen})_{3}\right]^{2+} \cdot{ }^{[17]}$ All complexes were found to have excited state lifetimes in the nanosecond range (Figure S15-S18) in an aerated environment (i.e., 72-193 ns) and in a degassed environment (i.e., 334-981 ns). These values are in the same range than for other reported $\mathrm{Ru}(\mathrm{II})$ polypyridine complexes. ${ }^{[18]}$

As the lifetimes drastically decrease in the presence of air, it indicates that the excited state can interact with a component of air. Capitalizing on this, the type of ROS generated upon light irradiation was then investigated by electron spin resonance spectroscopy using 2,2,6,6tetramethylpiperidine as a singlet oxygen $\left({ }^{1} \mathrm{O}_{2}\right)$ scavenger and 5,5-dimethyl-1-pyrroline $\mathrm{N}$ oxide as a ${ }^{\circ} \mathrm{OOH}$ or ${ }^{\bullet} \mathrm{OH}$ radical scavenger. In contrast to the characteristic ${ }^{1} \mathrm{O}_{2}$-induced triplet signal of 2,2,6,6-tetramethylpiperidinyloxyl in $\mathrm{CH}_{3} \mathrm{CN}$ and $\mathrm{PBS}$ for all complexes (Figure S19-S22), no significant signal was observed for the formation of ${ }^{\circ} \mathrm{OOH}$ or ${ }^{\circ} \mathrm{OH}$ radicals. The ${ }^{1} \mathrm{O}_{2}$ quantum yields upon light exposure were determined using two complementary methods: 1) directly by measuring the phosphorescence signal of ${ }^{1} \mathrm{O}_{2}$ upon excitation at $450 \mathrm{~nm} ; 2$ ) indirectly by capturing ${ }^{1} \mathrm{O}_{2}$ with a reporter molecule and monitoring its change by absorbance spectroscopy upon excitation at 450 or $540 \mathrm{~nm}$. The compounds (Table S2) were found to have ${ }^{1} \mathrm{O}_{2}$ quantum yields in $\mathrm{CH}_{3} \mathrm{CN}$ between $43-92 \%$ and 2-14 \% in an aqueous solution. The comparison between the compounds revealed that the ${ }^{1} \mathrm{O}_{2}$ production of $\mathbf{2 a}$ and $\mathbf{4 a}$ is drastically higher than of 1a and 3a, which is expected due to their superior photophysical properties. The ${ }^{1} \mathrm{O}_{2}$ generation of $\mathbf{2 a}$ and $\mathbf{4 a}$ is superior than their structurally related parent complexes $\left[\mathrm{Ru}(\text { phen })_{3}\right]^{2+}$ and $\left[\mathrm{Ru}(\text { bphen })_{3}\right]^{2+[17]}$ as well as their analogous bipy derivatives. ${ }^{[14]}$

The stability of a compound is a crucial factor in PDT applications. Previous studied have shown some metal complexes are not stable under physiological conditions, leading to undesired side effects. ${ }^{[19]}$ The compounds were incubated in human plasma at $37{ }^{\circ} \mathrm{C}$ and extracted after $48 \mathrm{~h}$. No significant differences between the chromatograms (Figure S23-S26) were observed, indicating that all complexes were stable in a biological environment. Following this, the stability upon light exposure at $540 \mathrm{~nm}$ was investigated by monitoring their absorption spectra. Previous studies have shown that this could be an issue for some $\mathrm{Ru}(\mathrm{II})$ complexes. ${ }^{[20]}$ It is important to note that clinically used PSs, represented here by protoporphyrin IX (PpIX), are generally associated with a fast photodegradation. ${ }^{[21]}$ The compounds investigated in this study were found to be highly photostable (Figure S27-S30) whereas PpIX completely decomposed (Figure S31) under identical experimental conditions. 
To study the effect that these complexes have on cells, we first assessed the time they need to be taken up by human cervical carcinoma (HeLa) cells using inductively coupled plasma mass spectrometry (ICP-MS). Within $6 \mathrm{~h}$, the asymptotic maximum concentration (Figure S32S35) was reached. The comparison between the complexes (Figure S36) shows that the bphen-coordinated complexes (3a, 4a) are slightly better taken up by cells than the phen coordinated complexes (1a, 2a). This result is in agreement with the determination of the $\log P$ values of the complexes (Table S3), which demonstrate their strong lipophilic character. Following this, the uptake mechanism of the compounds was investigated by blocking different pathways (Figure S37-S40) by preincubation with metabolic (2-deoxy- $D$-glucose and oligomycin), cationic transporter (tetraethylammonium chloride) and endocytotic (ammonium chloride or chloroquine) inhibitors as well as incubation at lower temperature (4 $\left.{ }^{\circ} \mathrm{C}\right) .{ }^{[22]}$ As the incubation with tetraethylammonium chloride had only a negligible effect on the uptake, the internalization by this pathway was ruled out. The change to lower temperatures as well as the incubation with metabolic inhibitors significantly decreased the uptake, indicating that the mechanism is energy dependent. As the preincubation with ammonium chloride or chloroquine strongly decreased the internalization of the complexes 1a-4a, it indicates that all compounds are taken up through an energy dependent endocytosis pathway. The subcellular localization was then examined using confocal laser scanning microscopy (Figure S41). The compounds were incubated in HeLa cells with commercial dyes for the major cellular organelles (i.e., nucleus, mitochondria, lysosomes, Golgi apparatus, endoplasmic reticulum) and their colocalization in the cells compared. As no significant overlap was observed, it suggests that the compounds do not majorly localize in these organelles. To further investigate the localization, the cell organelles were separately extracted and the amount of Ru determined by ICP-MS (Figure S42). All compounds were mainly found in the cytoplasm with small amounts of unselective accumulation. The structurally related bipy derivatives previously studied were also found to majorly localize in this organelle. ${ }^{[14]}$

To study the (photo-)cytotoxic effects of 1a-4a, these compounds were incubated in the dark as well as upon light exposure at $480 \mathrm{~nm}\left(10 \mathrm{~min}, 3.1 \mathrm{~J} / \mathrm{cm}^{2}\right)$ and $540 \mathrm{~nm}\left(40 \mathrm{~min}, 9.5 \mathrm{~J} / \mathrm{cm}^{2}\right)$ in non- cancerous retinal pigment epithelium (RPE-1), HeLa, mouse colon carcinoma (CT-26) and human glioblastoma astrocytoma (U373) cells. PpIX, the anticancer drug cisplatin and the parent complexes $\left[\mathrm{Ru}(\text { phen })_{3}\right]^{2+}$ and $\left[\mathrm{Ru}(\text { bphen })_{3}\right]^{2+}$ were used as controls. The light doses and irradiation times used in this work were optimized to the survival of the cells when treated only with the light source. All cell lines were tested identically to investigate the 
influence of the compounds on different types of cancer. The results (Table S4-S5) show that the phen-based compounds $(\mathbf{1 a}, \mathbf{2 a})$ as well as $\left[\mathrm{Ru}(\mathrm{phen})_{3}\right]^{2+}$ are non-toxic in the dark $\left(\mathrm{IC}_{50}>\right.$ $100 \mathrm{mM}$ ), which is a crucial requirement for PDT applications. On the contrary, the bphencoordinated complexes $(\mathbf{3 a}, \mathbf{4 a})$ were found to be cytotoxic in the low micromolar range $\left(\mathrm{IC}_{50}\right.$ $=5.2-20.8 \mu \mathrm{M})$ in all tested cell lines. The observed cytotoxicity in the dark for the bphencoordinated $\mathrm{Ru}(\mathrm{II})$ complexes could also be observed for $\left[\mathrm{Ru}(\text { bphen })_{3}\right]^{2+}$ and is in agreement with recent studies of structurally related bphen-coordinated compounds. ${ }^{[23]}$ Upon light irradiation, all compounds were able to generate ${ }^{1} \mathrm{O}_{2}$, causing cell death in all investigated cell lines. The phen-coordinated compounds (1a, 2a) were found to have a phototoxic effect in the low micromolar range $\left(\mathrm{IC}_{50}=0.9-15.6 \mu \mathrm{M}\right)$, while $\left[\mathrm{Ru}(\text { phen })_{3}\right]^{2+}$ only had a negligible effect. The bphen-coordinated complexes $(\mathbf{3 a}, \mathbf{4 a})$ as well as $\left[\mathrm{Ru}(\mathrm{bphen})_{3}\right]^{2+}$ have, next to a cytotoxic effect in the dark, a phototoxic effect, as demonstrated by their $\mathrm{IC}_{50}$ values in the high nanomolar to low micromolar range $\left(\mathrm{IC}_{50}=0.5-2.1 \mu \mathrm{M}\right)$. The L-OMe-based compounds (2a, 4a) were more phototoxic than the L-NMe ${ }_{2}$-based compounds $(\mathbf{1 a}, \mathbf{3 a})$. This observation is attributed to their superior photophysical properties (Table S1-S2), notably their better ${ }^{1} \mathrm{O}_{2}$ production. Overall, $2 \mathrm{a}$ was identified as the best compound of the series with no observed toxicity in the dark and a phototoxicity in the high nanomolar range in CT-26 cells $\left(\mathrm{IC}_{50,540 \mathrm{~nm}}=0.9 \pm 0.4 \mu \mathrm{M}, \mathrm{PI}_{540 \mathrm{~nm}}>111\right)$. These highly promising results of $2 \mathbf{a}$ are an order of magnitude lower compared to the $\mathrm{IC}_{50}$ values of the PS PpIX, the parent complex $\left[\mathrm{Ru}(\mathrm{phen})_{3}\right]^{2+}$ and cisplatin tested under identical experimental conditions.

The phototoxic profile of the lead compound 2a was further explored using longer wavelengths. 2a was also active upon irradiation at $595 \mathrm{~nm}\left(\mathbf{6 0} \mathrm{min}, \mathbf{1 1 . 2} \mathbf{J} / \mathbf{c m}^{2}\right)$ in CT-26 cells with an $\mathrm{IC}_{50}$ value in the low micromolar range $\left(\mathrm{IC}_{50,595 \mathrm{~nm}}=2.4 \pm 0.3 \mu \mathrm{M}, \mathrm{PI}_{595 \mathrm{~nm}}>\right.$ 41.7). In contrast, no phototoxicity was observed upon exposure to light at $620 \mathrm{~nm}(\mathbf{3 0} \mathbf{~ m i n}$, $\left.3.3 \mathrm{~J} / \mathrm{cm}^{2}\right)$. The cell death mechanism caused upon irradiation at $480 \mathrm{~nm}\left(10 \mathrm{~min}, 3.1 \mathrm{~J} / \mathrm{cm}^{2}\right)$ was investigated by determining the cell viability upon preincubation with autophagy (3methyladenine), apoptosis (Z-VAD-FMK), paraptosis (cycloheximide) and necrosis (necrostatin-1) inhibitors (Figure S43). Since preincubation with autophagy and necrosis inhibitors did not significantly influence the cell survival, these pathways were ruled out for all compounds. The preincubation with a paraptosis inhibitor slightly increased cell survival, while the preincubation with an apoptosis inhibitor highly increased cell survival. This indicates that the cell death is mainly caused by the apoptosis pathway, with minor contribution from the paraptosis pathway. Some previously studied PS were triggering cell death by the same mechanism. ${ }^{[24]}$ To further investigate the apoptosis mechanism, its 
dependency on caspases 3/7 was studied. Caspases 3/7 are well known executers of the intrinsic and extrinsic apoptosis mechanism. ${ }^{[25]}$ The caspase activity was measured in HeLa cells upon irradiation at $480 \mathrm{~nm}\left(10 \mathrm{~min}, 3.1 \mathrm{~J} / \mathrm{cm}^{2}\right)$. The results show highly increased caspase levels upon irradiation (Figure S44), indicating that the phototoxic effect of all compounds is caused by a caspase $3 / 7$ pathway. Some previously studied $\mathrm{Ru}(\mathrm{II})$ polypyridine complexes were found to exert their phototoxic effect by the same mechanism. ${ }^{[26]}$

a)

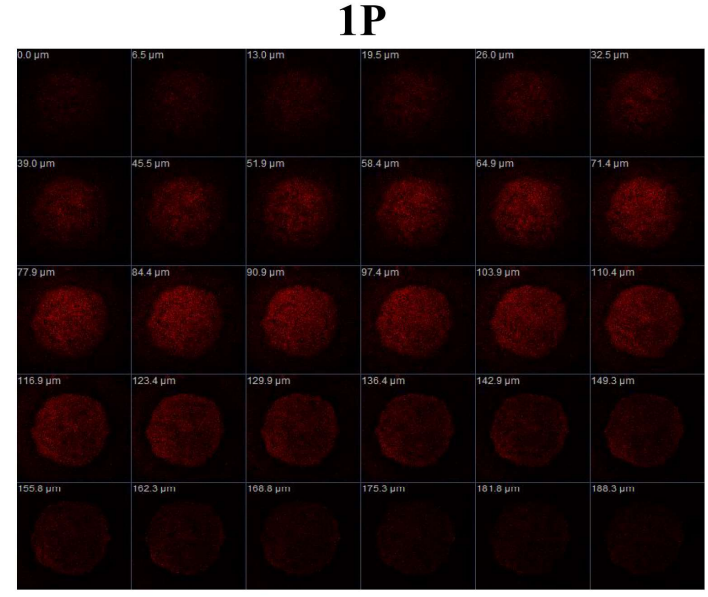

b)

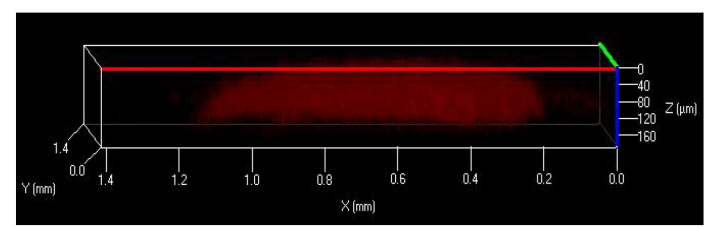

2P

c)

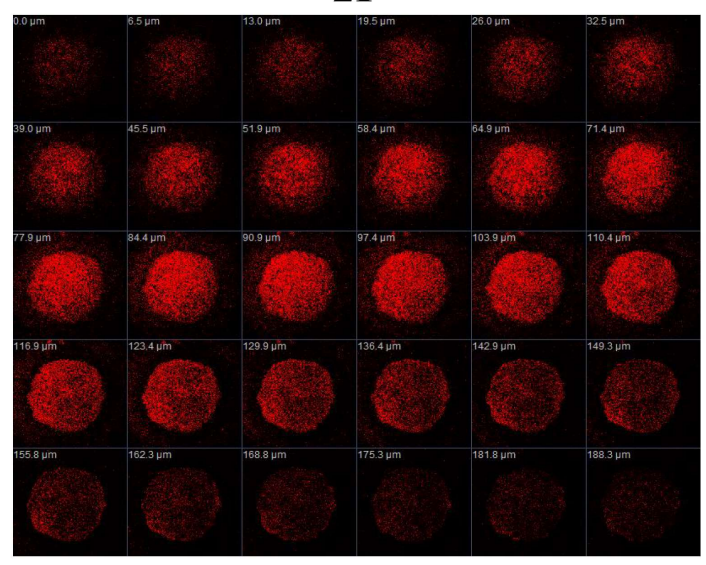

d)

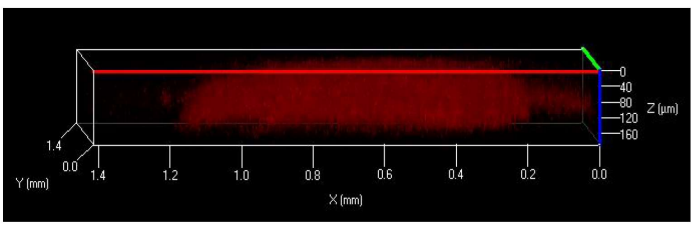

Figure 2. $1 \mathrm{P}\left(\lambda_{\mathrm{ex}}=458 \mathrm{~nm}, \lambda_{\mathrm{em}}=600-750 \mathrm{~nm}\right)$ and $2 \mathrm{P}\left(\lambda_{\mathrm{ex}}=800 \mathrm{~nm}, \lambda_{\mathrm{em}}=600-750 \mathrm{~nm}\right)$ excited Z-stack images in HeLa MCTS after incubation of $2 \mathbf{a}(10 \mu \mathrm{M})$ for $12 \mathrm{~h}$. a/c) Z-axis 
images scanning from the top to the bottom of an intact spheroid. b/d) 3D z-stack of an intact spheroid.

As a closer model to clinically treated cancer tumors, the biological effects of the compounds were evaluated in-depth in exceptionally large 3D multicellular tumour spheroids (MCTSs) with a diameter of $800 \mu \mathrm{m}$. In addition to the irradiation with a 1P light source, we have also studied their biological effect using a $2 \mathrm{P}$ light source. To investigate the penetration of the compounds inside the tumour model, HeLa MCTSs were incubated with 1a-4a $(10 \mu \mathrm{M})$ for $12 \mathrm{~h}$ and their 1P and 2P luminescence images by laser scanning confocal z-stack microscopy taken. Importantly, all compounds were able to fully penetrate the MCTSs up to their central cores, as demonstrated by the strong luminescence signal at every section depth (Figure 2, Figure S45-S47). A stronger luminescence signal following the $2 \mathrm{P}$ excitation in comparison to the 1P excitation was observed due to the deeper light penetration inside the MCTSs. Following this, the capacity of the compounds to generate ${ }^{1} \mathrm{O}_{2}$ upon irradiation inside the hypoxic centre of the MCTSs was investigated. For this purpose, HeLa MCTSs were incubated with 2',7'-dichlorofluorescein diacetate (DCFH-DA), which is converted into the highly fluorescent 2',7'-dichlorofluorescein in the presence of ROS. While no green fluorescence signal was observed in the dark, upon $2 \mathrm{P}$ irradiation $\left(800 \mathrm{~nm}, 2 \mathrm{~J} / \mathrm{cm}^{2}\right.$, section interval of $5 \mu \mathrm{m}$ ), a strong signal in the whole MCTSs was detected (Figure 3). Strikingly, the signal was also observed in the centre of the MCTSs, suggesting the generation of ${ }^{1} \mathrm{O}_{2}$ despite the hypoxic conditions, which are typically observed in MCTS.

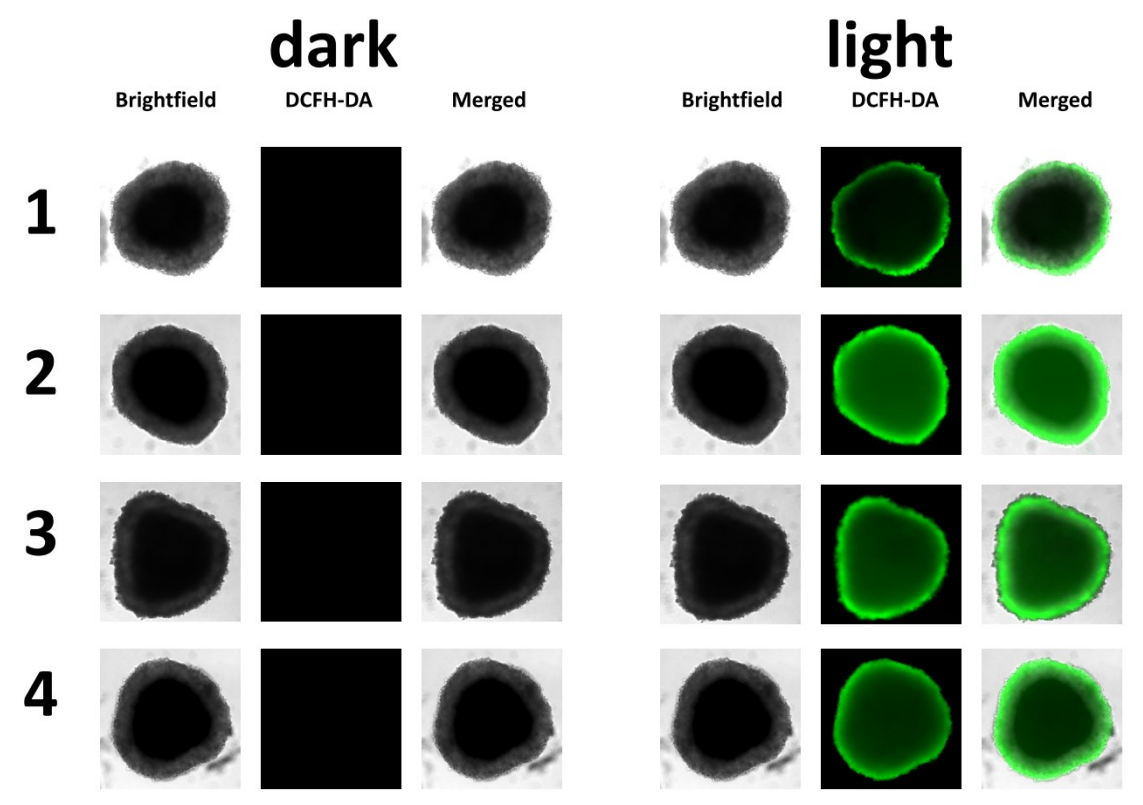


Figure 3. Confocal fluorescent images of HeLa MCTSs incubated with DCFH-DA and the compounds 1a-4a $(2 \mu \mathrm{M})$ kept in the dark and after a $2 \mathrm{P}$ irradiation $\left(800 \mathrm{~nm}, 2 \mathrm{~J} / \mathrm{cm}^{2}\right.$, section interval of $5 \mu \mathrm{m})$.

To study the (photo-)cytotoxic effect in MCTSs, 1a-4a $(20 \mu \mathrm{M})$, cisplatin $(10 \mu \mathrm{M}$ and $30 \mu \mathrm{M})$ and the well-characterized PS tetraphenylporphyrin $\left(\mathrm{H}_{2} \mathrm{TPP}, 20 \mu \mathrm{M}\right)$ were exposed to $1 \mathrm{P}(500$ $\left.\mathrm{nm}, 10 \mathrm{~J} / \mathrm{cm}^{2}\right)$ and $2 \mathrm{P}\left(800 \mathrm{~nm}, 10 \mathrm{~J} / \mathrm{cm}^{2}\right.$, section interval of $\left.5 \mu \mathrm{m}\right)$ irradiation and their tumour growth monitored (Figure 4). As observed in 2D monolayer cells, 3a and 4a showed a weak tumour growth inhibition effect in the dark similar to cisplatin at $10 \mu \mathrm{M}$ while 1a and 2a did not significantly influence the tumour growth in the dark - the MTCSs grew in similar manner as the control. Upon 1P or 2P light treatment, all compounds 1a-4a were able to cause a phototoxic effect inside the MCTSs leading to a decrease of the volume of the MCTSs. In particular, the compounds $\mathbf{2 a}$ and $\mathbf{4 a}$ drastically decreased the tumour growth upon light exposure, demonstrating their ability to act efficiently as a PS inside a 3D cellular architecture. Under identical conditions, the MCTSs treated with $\mathrm{H}_{2}$ TPP did not show any significant effects, highlighting the superior ability of these compounds.

a)

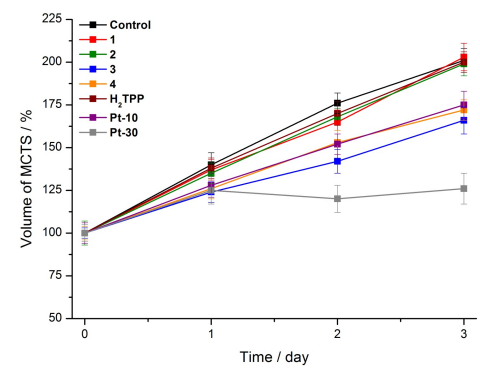

b)

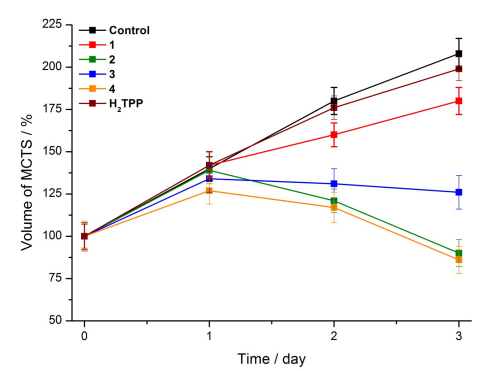

c)

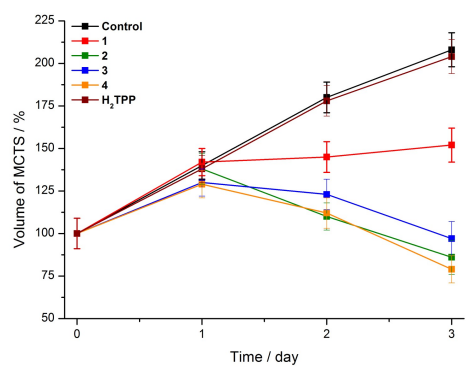

Figure 4. Tumour growth inhibition assay. Change of the volume in HeLa MCTSs in correlation to treatment time. The MCTSs were treated with the compounds 1a-4a $(20 \mu \mathrm{M})$, $\mathrm{H}_{2} \mathrm{TPP}(20 \mu \mathrm{M})$ and cisplatin $(10 \mu \mathrm{M}$ and $30 \mu \mathrm{M})$. The MCTSs were a) strictly kept in the dark b) exposed to a $1 \mathrm{P}$ irradiation $\left(500 \mathrm{~nm}, 10 \mathrm{~J} / \mathrm{cm}^{2}\right)$ c) exposed to a $2 \mathrm{P}$ irradiation $(800 \mathrm{~nm}$, $10 \mathrm{~J} / \mathrm{cm}^{2}$, section interval of $5 \mu \mathrm{m}$ ) on day 1 . Representative pictures of the MCTSs can be found in Figure S48-S50. The error bars correspond to the standard deviation of the three replicates.

To perform a deeper investigation of the phototoxic effect caused by the $\mathrm{Ru}(\mathrm{II})$ polypyridine complexes, the treated MCTSs were stained with calcein AM and propidium iodide to 
differentiate between living and dead cells. While the non-fluorescent calcein AM is converted to the highly green fluorescent calcein in living cells, propidium iodide is only able to penetrate dead cells with a damaged membrane integrity. It can then intercalate into DNA, causing a strong red fluorescence. As observed during the 2D monolayer screening, a significant dark cytotoxicity was detected for compounds 3a and 4a, while 1a and 2a showed no signs of cell death. Upon 1P or 2P irradiation, the vast majority of the MCTSs consisted of dead cells, as indicated by the strong red fluorescence signal of propidium iodide inside the MCTSs (Figure 5). Cellular damage was also caused in the large hypoxic centre, which remains so far a major challenge during a PDT treatment.

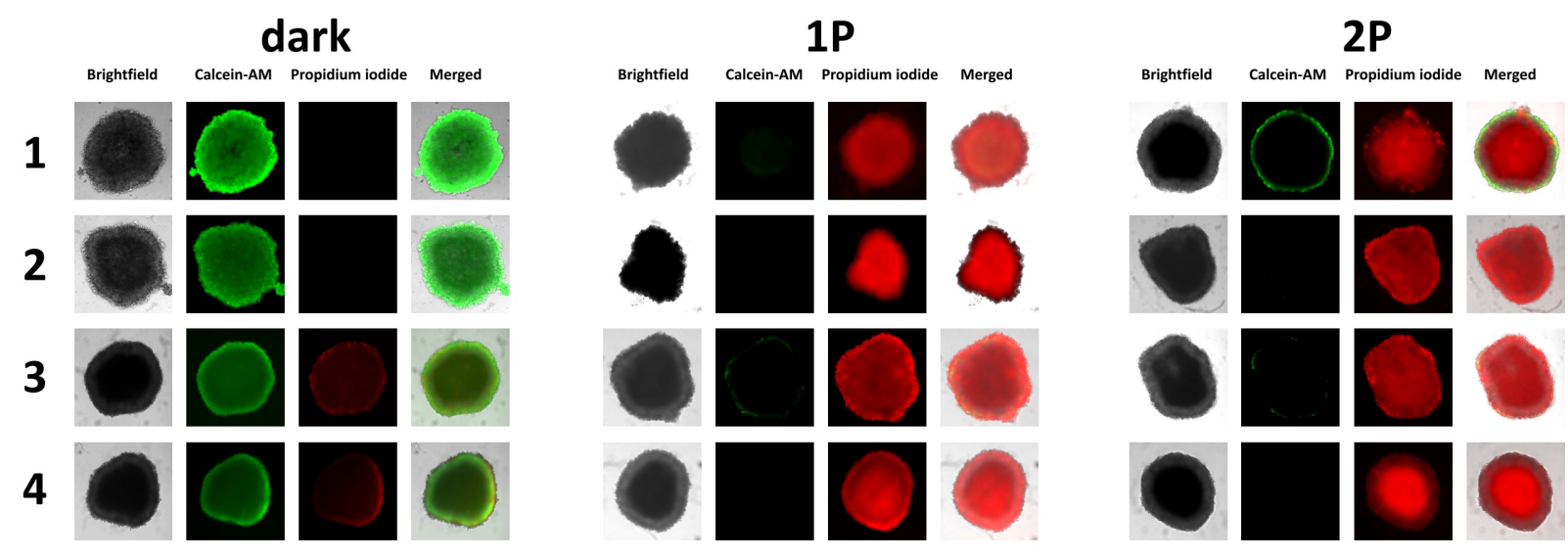

Figure 5. Representative image of the viability assay with HeLa MCTSs kept in the dark and exposed to light. MCTS were treated with the compounds 1-4 $(20 \mu \mathrm{M})$ in the dark for $12 \mathrm{~h}$. After this time, MCTSs were exposed to a $1 \mathrm{P}\left(500 \mathrm{~nm}, 10 \mathrm{~J} / \mathrm{cm}^{2}\right)$ or a $2 \mathrm{P}$ irradiation $(800 \mathrm{~nm}$, $10 \mathrm{~J} / \mathrm{cm}^{2}$, section interval of $5 \mu \mathrm{m}$ ). After 2 days, the cell survival was assessed by measurement of the fluorescence of calcein $\left(\lambda_{\mathrm{ex}}=495 \mathrm{~nm}, \lambda_{\mathrm{em}}=515 \mathrm{~nm}\right)$ and cell death by measurement of the fluorescence of propidium iodide $\left(\lambda_{\mathrm{ex}}=536 \mathrm{~nm}, \lambda_{\mathrm{em}}=617 \mathrm{~nm}\right)$.

To further study and quantify the (photo-)cytotoxic effect of the complexes, their $\mathrm{IC}_{50}$ values in MCTSs in the dark as well as upon $1 \mathrm{P}\left(500 \mathrm{~nm}, 10 \mathrm{~J} / \mathrm{cm}^{2}\right)$ and $2 \mathrm{P}\left(800 \mathrm{~nm}, 10 \mathrm{~J} / \mathrm{cm}^{2}\right.$, section interval of $5 \mu \mathrm{m}$ ) excitation were determined by measuring their ATP concentration. The obtained results (Table 1) are in agreement with the tumour growth inhibition assay, showing that the bphen-coordinated complexes $(\mathbf{3 a}, \mathbf{4 a})$ have a cytotoxic effect in the low micromolar range in the dark while the phen-coordinated complexes (1a, 2a) showed no dark toxicity even up to high micromolar range $\left(\mathrm{IC}_{50}>300 \mu \mathrm{M}\right)$. Upon exposure to $1 \mathrm{P}$ or $2 \mathrm{P}$ irradiation, all compounds were able to cause a phototoxic effect in the micromolar range $\left(\mathrm{IC}_{50,1 \mathrm{P}}=3.8-32.6 \mu \mathrm{M}, \mathrm{IC}_{50,2 \mathrm{P}}=0.8-27.8 \mu \mathrm{M}\right)$. As the lead compound of this study, 2a demonstrated its remarkable ability as a PS with PI values of $>40$ upon $1 \mathrm{P}$ and $>250$ upon $2 \mathrm{P}$ 
irradiation. Further, 2a was also found to be phototoxic in HeLa MCTSs upon irradiation at $595 \mathrm{~nm}\left(60 \mathrm{~min}, 11.2 \mathrm{~J} / \mathrm{cm}^{2}\right)$ in the low micromolar range $\left(\mathrm{IC}_{50,595 \mathrm{~nm}}=16.7 \pm 1.2 \mu \mathrm{M}, \mathrm{PI}_{595 \mathrm{~nm}}\right.$ $>18$ ). Overall, the lead compound 2 was found to have a two order of magnitudes higher phototoxicity in comparison to $\mathrm{H}_{2} \mathrm{TPP}$, indicating that the compounds reported here can act using very low drug and light doses.

Table 1. $\mathrm{IC}_{50}$ values in the dark as well as upon $1 \mathrm{P}\left(500 \mathrm{~nm}, 10 \mathrm{~J} / \mathrm{cm}^{2}\right)$ and $2 \mathrm{P}(800 \mathrm{~nm}, 10$ $\mathrm{J} / \mathrm{cm}^{2}$, section interval of $5 \mu \mathrm{m}$ ) irradiation of 1a-4a as well as of cisplatin and $\mathrm{H}_{2} \mathrm{TPP}$ in HeLa 3D MCTS. Average of three independent measurements. n.d. = not determinable.

\begin{tabular}{|l|c|c|c|c|c|}
\hline & dark & $\mathbf{1 P}$ & PI & 2P & PI \\
\hline $\mathbf{1}$ & $>300$ & $32.6 \pm 2.5$ & $>9.2$ & $27.8 \pm 3.1$ & $>10.8$ \\
\hline $\mathbf{2}$ & $>300$ & $7.5 \pm 0.2$ & $>40.0$ & $1.2 \pm 0.3$ & $>250.0$ \\
\hline $\mathbf{3}$ & $27.8 \pm 3.6$ & $8.9 \pm 0.7$ & 3.1 & $3.1 \pm 0.6$ & 9.0 \\
\hline $\mathbf{4}$ & $29.3 \pm 2.9$ & $3.8 \pm 0.4$ & 7.7 & $0.8 \pm 0.5$ & 36.6 \\
\hline $\mathbf{H} 2$ TPP & $>100$ & $>100$ & n.d. & $>100$ & n.d. \\
\hline cisplatin & $18.6 \pm 1.3$ & - & - & - & - \\
\hline
\end{tabular}

For a further investigation, the biological properties of $\mathbf{2}$ inside a mouse model was investigated. As the counter ion of a metal complex can have a significant effect on the overall ability of the compound including its water solubility or toxicity ${ }^{[27]}, \mathbf{2 a}$ was converted into the chloride salt $\mathbf{2 b}$ using a counter ion exchange resin. The biodistribution of the compound inside of nude mice bearing an adenocarcinomic human alveolar basal epithelial (A549) tumour upon intravenous tail-injection was time-dependently $(0.5,1,2,4 \mathrm{~h})$ studied. At each time point, the mice were sacrificed, all major organs collected (i.e., blood, spleen, intestine, gastric, liver, kidney, lung, heart, brain, tumour), ground and the amount of Ru inside each organ determined by ICP-MS (Figure S51). The compound was rapidly absorbed from the blood stream, accumulating mainly within the liver and kidney. The compound also accumulated inside the tumour with a concentration maximum $2 \mathrm{~h}$ after the injection. Capitalizing on these results, in vivo PDT experiments were performed using a $1 \mathrm{P}(500 \mathrm{~nm}$, $\left.10 \mathrm{~mW} / \mathrm{cm}^{2}, 15 \mathrm{~min}\right)$ or $2 \mathrm{P}$ irradiation $(800 \mathrm{~nm}, 50 \mathrm{~mW}, 1 \mathrm{kHz}$, pulse width $35 \mathrm{fs}, 5 \mathrm{~s} / \mathrm{mm})$ 
light treatment on days 1, 4 and 7. Encouragingly, the PDT treated tumours drastically shrank until they were nearly eradicated. It is important to mention that while the tumours treated with a $2 \mathrm{P}$ light source did not show a significant growth after the treatment, the tumours treated with a 1P light source did indicate a small tumour growth. We assume that this could be caused by the deeper light tissue penetration of $2 \mathrm{P}$ irradiation compared to $1 \mathrm{P}$. In contrast, the tumours only treated by light or with the compound did not show any tumour inhibition effect (Figures $6 \mathrm{a}$ and $6 \mathrm{c}$ ). The animals treated with the compound behaved normally, without signs of pain, stress or discomfort and did not lose or gain weight (Figure 6b). After 17 days (representative picture: Figure S52), all mice were sacrificed and the tumour and organs separated. As excepted, using a histological examination with an H\&E stain the tumour tissue showed noticeable pathological alterations (Figure S53) while all major organs did not show any pathological effect (Figure S54).

a)

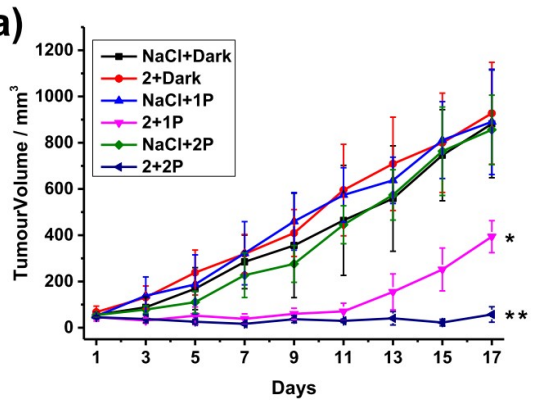

b)

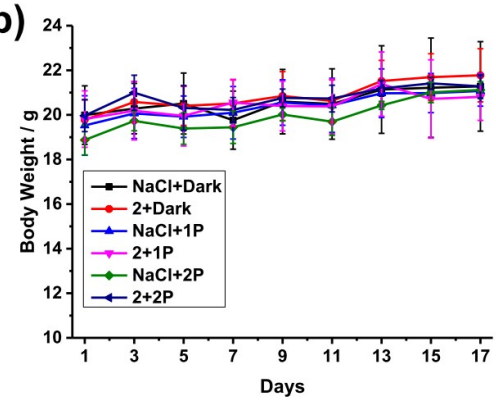

c)

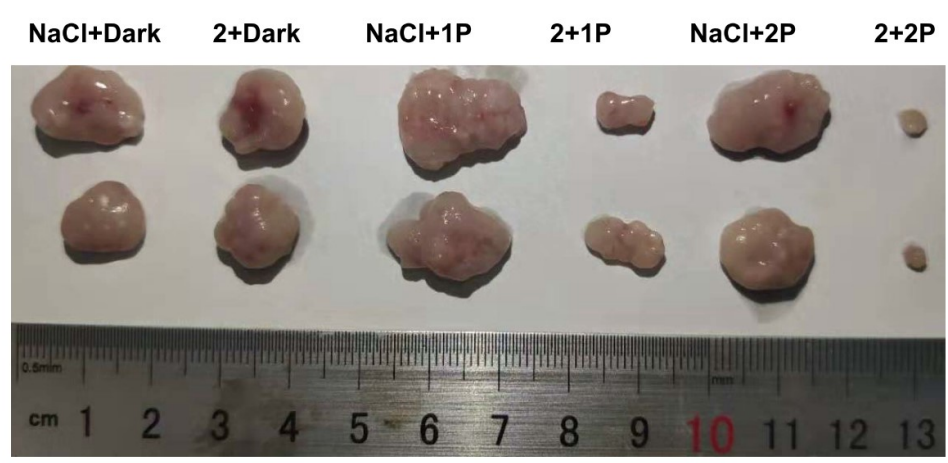

Figure 6. In vivo PDT study of $\mathbf{2 b}$ using $1 \mathrm{P}\left(500 \mathrm{~nm}, 10 \mathrm{~mW} / \mathrm{cm}^{2}, 15 \mathrm{~min}\right)$ or $2 \mathrm{P}(800 \mathrm{~nm}, 50$ $\mathrm{mW}, 1 \mathrm{kHz}$, pulse width $35 \mathrm{fs}, 5 \mathrm{~s} / \mathrm{mm}$ ) excitation on nude mice bearing an adenocarcinomic human alveolar basal epithelial cancer tumour. a) Tumour growth inhibition curves upon treatment. b) Average body weights of the tumour-bearing mice. c) Representative photographs of the tumour after different treatments on day $17 .{ }^{*} p<0.05,{ }^{*} p<0.01$.

\section{CONCLUSION}


In summary, a series of new asymmetric substituted 1,10-phenenthroline and 4,7-diphenyl1,10-phenanthroline $\mathrm{Ru}(\mathrm{II})$ polypyridine complexes is presented as efficient PSs for 1- and 2Photon PDT. The complexes showed a red shifted 1-Photon absorption towards and exceptionally strong 2-Photon absorption in the biological spectral window. They were found to enter cells by an energy dependent endocytosis mechanism, where the complexes accumulated primarily in the cytoplasm. Upon irradiation in various 2D monolayer cancer cell lines, the complexes caused cell death in the high nanomolar/low micromolar range by apoptosis utilising the caspase $3 / 7$ pathway. Following this, the efficiency of the compounds was investigated in exceptionally large MCTSs with a diameter of $800 \mu \mathrm{m}$, which can better simulate the pathological conditions found in clinically-relevant tumors. All complexes were able to fully penetrate the MCTSs and to generate singlet oxygen in their hypoxic centres. Strikingly, after the treatment, the MCTSs were fully eradicated, including in their large hypoxic centres. While the lead compound of this study, 2 was found to be non-toxic in the dark, it is highly phototoxic in MCTSs in the very low micromolar range upon 1-Photon (595 $\mathrm{nm})$ or 2-Photon $(800 \mathrm{~nm})$ irradiation. Worthy of note, in comparison to the previously published 2,2'-bipyridine analogous compounds, these complexes were found to be photoactive upon even longer wavelengths by 1-Photon irradiation. In addition, 2 was also able to eradicate an adenocarcinomic human alveolar basal epithelial tumour inside a mouse model upon clinically relevant 1-Photon $(500 \mathrm{~nm})$ or 2-Photon $(800 \mathrm{~nm})$ excitation, demonstrating its high potential as a PS. Overall, the compounds presented in this study can overcome the limitations of currently applied PSs. We strongly believe that these complexes, especially 2, has great potential for 1- and 2- Photon excited PDT and is a suitable candidate for further clinical investigations.

\section{ACKNOWLEDGEMENTS}

We thank Dr. Philippe Goldner for access to state-of-the-art laser apparatus. This work was financially supported by an ERC Consolidator Grant PhotoMedMet to G.G. (GA 681679), has received support under the program "Investissements d' Avenir" launched by the French Government and implemented by the ANR with the reference ANR-10-IDEX-0001-02 PSL (G.G.), the National Science Foundation of China (Nos. 21525105 and 21778079 for H.C.) and the 973 Program (No. 2015CB856301 for H.C.). 


\section{AUTHOR CONTRIBUTIONS}

J. K., S. K., H. C. and G. G. were involved with the design and interpretation of experiments and with the writing of the manuscript. Chemical, photophysical and biological cellular experiments were carried out by J.K. Animal testing was carried out by S. K. Comments on the English writing style were provided by Y. C. O. The work was supervised by H. C. and G. G. All authors have given approval to the final version of the manuscript. 


\section{REFERENCES}

[1] a)S. Bonnet, Dalton Trans. 2018, 47, 10330-10343; b)S. Callaghan, M. O. Senge, Photochem. Photobiol. Sci. 2018, 17, 1490-1514; c)P.-C. Lo, M. S. RodríguezMorgade, R. K. Pandey, D. K. P. Ng, T. Torres, F. Dumoulin, Chem. Soc. Rev. 2020, 49, 1041-1056; d)F. Heinemann, J. Karges, G. Gasser, Acc. Chem. Res. 2017, 50, 2727-2736.

[2] B. Muz, P. de la Puente, F. Azab, A. K. Azab, Hypoxia 2015, 3, 83-92.

[3] a)C. A. Robertson, D. H. Evans, H. Abrahamse, J. Photochem. Photobiol. B. 2009, 96, 1-8; b)S. Mallidi, S. Anbil, A.-L. Bulin, G. Obaid, M. Ichikawa, T. Hasan, Theranostics 2016, 6, 2458-2487; c)C. Imberti, P. Zhang, H. Huang, P. J. Sadler, Angew. Chem. Int. Ed., 2020, 59, 61-73; d)F. Dumoulin, Photodiagnosis Photodyn. Ther. 2017, 17, A4 - A78.

[4] a)R. M. Sutherland, Science 1988, 240, 177-184; b)P. A. Netti, D. A. Berk, M. A. Swartz, A. J. Grodzinsky, R. K. Jain, Cancer Res. 2000, 60, 2497-2503; c)S. Riffle, R. S. Hegde, J. Exp. Clin. Cancer Res. 2017, 36, 102-112; d)P. J. Dyson, Natl. Sci. Rev. 2019, 6, 1068-1069.

[5] a)L. A. Kunz-Schughart, Cell Biol. Int. 1999, 23, 157-161; b)J. Friedrich, C. Seidel, R. Ebner, L. A. Kunz-Schughart, Nat. Protoc. 2009, 4, 309-324

[6] a)I. Freitas, Tumori J. 1985, 71, 251-259; b)M. Höckel, P. Vaupel, J. Natl. Cancer Inst. 2001, 93, 266-276; c)L. N. Lameijer, D. Ernst, S. L. Hopkins, M. S. Meijer, S. H. C. Askes, S. E. Le Dévédec, S. Bonnet, Angew. Chem. Int. Ed. 2017, 56, 1154911553; d)J. Fong, K. Kasimova, Y. Arenas, P. Kaspler, S. Lazic, A. Mandel, L. Lilge, Photochem. Photobiol. Sci. 2015, 14, 2014-2023; e)P. Zhang, P. J. Sadler, Eur. J. Inorg. Chem. 2017, 2017, 1541-1548; f)H. Huang, S. Banerjee, K. Qiu, P. Zhang, O. Blacque, T. Malcomson, M. J. Paterson, G. J. Clarkson, M. Staniforth, V. G. Stavros, G. Gasser, H. Chao, P. J. Sadler, Nat. Chem. 2019, 11, 1041-1048; g)J. Roque III, D. Havrylyuk, P. C. Barrett, T. Sainuddin, J. McCain, K. Colón, W. T. Sparks, E. Bradner, S. Monro, D. Heidary, C. G. Cameron, E. C. Glazer, S. A. McFarland, Photochem. Photobiol. 2019,2, 327-339

[7] A. Raza, S. A. Archer, S. D. Fairbanks, K. L. Smitten, S. W. Botchway, J. A. Thomas, S. MacNeil, J. W. Haycock, J. Am. Chem. Soc. 2020, 142, 4639-4647.

[8] a)D. R. Grimes, C. Kelly, K. Bloch, M. Partridge, J. R. Soc. Interface 2014, 11, 20131124; b)W. R. Wilson, M. P. Hay, Nat. Rev. Cancer 2011, 11, 393-410. 
[9] a)H. Huang, B. Yu, P. Zhang, J. Huang, Y. Chen, G. Gasser, L. Ji, H. Chao, Angew. Chem. Int. Ed. 2015, 54, 14049-14052; b)B. S. Howerton, D. K. Heidary, E. C. Glazer, J. Am. Chem. Soc. 2012, 134, 8324-8327; c)V. H. S. van Rixel, V. Ramu, A. B. Auyeung, N. Beztsinna, D. Y. Leger, L. N. Lameijer, S. T. Hilt, S. E. Le Dévédec, T. Yildiz, T. Betancourt, M. B. Gildner, T. W. Hudnall, V. Sol, B. Liagre, A. Kornienko, S. Bonnet, J. Am. Chem. Soc. 2019, 141, 18444-18454.

[10] a)R. Lincoln, L. Kohler, S. Monro, H. Yin, M. Stephenson, R. Zong, A. Chouai, C. Dorsey, R. Hennigar, R. P. Thummel, S. A. McFarland, J. Am. Chem. Soc. 2013, 135, 17161-17175; b)A. M. Palmer, B. Peña, R. B. Sears, O. Chen, M. E. Ojaimi, R. P. Thummel, K. R. Dunbar, C. Turro, Philos. Trans. R. Soc. A 2013, 371, 20120135; c)J. Yellol, S. A. Pérez, A. Buceta, G. Yellol, A. Donaire, P. Szumlas, P. J. Bednarski, G. Makhloufi, C. Janiak, A. Espinosa, J. Ruiz, J. Med. Chem. 2015, 58, 7310-7327; d)F. E. Poynton, S. A. Bright, S. Blasco, D. C. Williams, J. M. Kelly, T. Gunnlaugsson, Chem. Soc. Rev. 2017, 46, 7706-7756; e)A. Li, C. Turro, J. J. Kodanko, Acc. Chem. Res. 2018, 51, 1415-1421; f)R. F. Brissos, P. Clavero, A. Gallen, A. Grabulosa, L. A. Barrios, A. B. Caballero, L. Korrodi-Gregório, R. Pérez-Tomás, G. Muller, V. SotoCerrato, P. Gamez, Inorg. Chem. 2018, 57, 14786-14797; g)J. Shum, P. K.-K. Leung, K. K.-W. Lo, Inorg. Chem. 2019, 58, 2231-2247; h)J. Karges, F. Heinemann, F. Maschietto, M. Patra, O. Blacque, I. Ciofini, B. Spingler, G. Gasser, Biorg. Med. Chem. 2019, 27, 2666-2675; i)S. Monro, K. L. Colón, H. Yin, J. Roque III, P. Konda, S. Gujar, R. P. Thummel, L. Lilge, C. G. Cameron, S. A. McFarland, Chem. Rev. 2019, 119, 797-828; i)M. S. Meijer, S. Bonnet, Inorg. Chem. 2019, 58, 11689-11698; j)P. J. Jarman, F. Noakes, S. Fairbanks, K. Smitten, I. K. Griffiths, H. K. Saeed, J. A. Thomas, C. Smythe, J. Am. Chem. Soc. 2019, 141, 2925-2937; k)J. Karges, T. Yempala, M. Tharaud, D. Gibson, G. Gasser, Angew. Chem. 2020, 59, 7069-7075 ; 1)N. Soliman, L. K. McKenzie, J. Karges, E. Bertrand, M. Tharaud, M. Jakubaszek, V. Guérineau, B. Goud, M. Hollenstein, G. Gasser, C. M. Thomas, Chem. Sci. 2020, 11, 2657-2663; m)N. P. Toupin, S. Nadella, S. J. Steinke, C. Turro, J. J. Kodanko, Inorg. Chem. 2020, 59, 3919-3933.

[11] a)P. Kaspler, S. Lazic, S. Forward, Y. Arenas, A. Mandel, L. Lilge, Photochem. Photobiol. Sci. 2016, 15, 481-495; b)V. Novohradsky, A. Rovira, C. Hally, A. Galindo, G. Vigueras, A. Gandioso, M. Svitelova, R. Bresolí-Obach, H. Kostrhunova, L. Markova, J. Kasparkova, S. Nonell, J. Ruiz, V. Brabec, V. Marchán, Angew. Chem. Int. Ed. 2019, 58, 6311-6315; c)J. Karges, O. Blacque, P. Goldner, H. Chao, G. 
Gasser, Eur. J. Inorg. Chem., 2019, 2019 , 3704-3712; d)D. Havrylyuk, K. Stevens, S. Parkin, E. C. Glazer, Inorg. Chem. 2020, 59, 1006-1013.

[12] a)C. Girardot, G. Lemercier, J. C. Mulatier, J. Chauvin, P. L. Baldeck, C. Andraud, Dalton Trans. 2007, 3421-3426; b)S. C. Boca, M. Four, A. Bonne, B. Van Der Sanden, S. Astilean, P. L. Baldeck, G. Lemercier, Chem. Commun. 2009, 4590-4592; c)J. Liu, Y. Chen, G. Li, P. Zhang, C. Jin, L. Zeng, L. Ji, H. Chao, Biomaterials 2015, 56, 140-153; d)L. Zeng, S. Kuang, G. Li, C. Jin, L. Ji, H. Chao, Chem. Commun. 2017, 53, 1977-1980; e)K. Qiu, J. Wang, C. Song, L. Wang, H. Zhu, H. Huang, J. Huang, H. Wang, L. Ji, H. Chao, ACS Appl. Mater. Interfaces 2017, 9, 18482-18492; f)J. Hess, H. Huang, A. Kaiser, V. Pierroz, O. Blacque, H. Chao, G. Gasser, Chem. Eur. J. 2017, 41, 9888-9896.

[13] a)M. Drobizhev, Y. Stepanenko, Y. Dzenis, A. Karotki, A. Rebane, P. N. Taylor, H. L. Anderson, J. Phys. Chem. B 2005, 109, 7223-7236; b)T. K. Ahn, K. S. Kim, D. Y. Kim, S. B. Noh, N. Aratani, C. Ikeda, A. Osuka, D. Kim, J. Am. Chem. Soc. 2006, 128, 1700-1704; c)M.-C. Yoon, S. B. Noh, A. Tsuda, Y. Nakamura, A. Osuka, D. Kim, J. Am. Chem. Soc. 2007, 129, 10080-10081; d)M. Pawlicki, H. A. Collins, R. G. Denning, H. L. Anderson, Angew. Chem. Int. Ed. 2009, 48, 3244-3266.

[14] J. Karges, S. Kuang, F. Maschietto, O. Blacque, I. Ciofini, H. Chao, G. Gasser, Nat. Commun. 2020, 11, 3262 .

[15] a)C. Feuvrie, O. Maury, H. Le Bozec, I. Ledoux, J. P. Morrall, G. T. Dalton, M. Samoc, M. G. Humphrey, J. Phys. Chem. A 2007, 111, 8980-8985; b)M. G. Humphrey, T. Schwich, P. J. West, M. P. Cifuentes, M. Samoc, Comprehensive Inorganic Chemistry II (Second Edition) (Eds.: J. Reedijk, K. Poeppelmeier), Elsevier, Amsterdam, 2013, 781-835.

[16] B. P. Sullivan, D. J. Salmon, T. J. Meyer, Inorg. Chem. 1978, 17, 3334-3341.

[17] D. Garcìa-Fresnadillo, Y. Georgiadou, G. Orellana, A. M. Braun, E. Oliveros, Helv. Chim. Acta 1996, 79, 1222-1238.

[18] a)M. J. Cook, A. P. Lewis, G. S. McAuliffe, V. Skarda, A. J. Thomson, J. L. Glasper, D. J. Robbins, J. Chem. Soc., Perkin Trans. 2 1984, 1293-1301; b)V. Balzani, A. Juris, Coord. Chem. Rev. 2001, 211, 97-115.

[19] a)M. D. Hall, K. A. Telma, K.-E. Chang, T. D. Lee, J. P. Madigan, J. R. Lloyd, I. S. Goldlust, J. D. Hoeschele, M. M. Gottesman, Cancer Res. 2014, 74, 3913-3922; b)S. Keller, Y. C. Ong, Y. Lin, K. Cariou, G. Gasser, J. Organomet. Chem. 2019, 121059; 
[20] a)U. Basu, J. Karges, F. Chotard, C. Balan, P. Le Gendre, G. Gasser, E. Bodio, R. Malacea Kabbara, Polyhedron 2019, 172, 22-27; b)A. K. Renfrew, J. Karges, R. Scopelliti, F. D. Bobbink, P. Nowak-Sliwinska, G. Gasser, P. Dyson, ChemBioChem 2019, 20, 2876-2882.

[21] a)T. S. Mang, T. J. Dougherty, W. R. Potter, D. G. Boyle, S. Somer, J. Moan, Photochem. Photobiol. 1987, 45, 501-506; b)J. Moan, G. Streckyte, S. Bagdonas, Ø. Bech, K. Berg, Int. J. Cancer 1997, 70, 90-97.

[22] a)J. Karges, U. Basu, O. Blacque, H. Chao, G. Gasser, Angew. Chem. Int. Ed., 2019, 58, 14334-14340; b)J. Karges, O. Blacque, H. Chao, G. Gasser, Inorg. Chem. 2019, $58,12422-12432$.

[23] a)C. Tan, S. Wu, S. Lai, M. Wang, Y. Chen, L. Zhou, Y. Zhu, W. Lian, W. Peng, L. Ji, A. Xu, Dalton Trans. 2011, 40, 8611-8621; b)M. R. Gill, D. Cecchin, M. G. Walker, R. S. Mulla, G. Battaglia, C. Smythe, J. A. Thomas, Chem. Sci. 2013, 4, 4512-4519; c)M. Dickerson, Y. Sun, [1] a)S. Bonnet, Dalton Trans. 2018, 47, 10330-10343; b)S. Callaghan, M. O. Senge, Photochem. Photobiol. Sci. 2018, 17, 1490-1514; c)P.-C. Lo, M. S. Rodríguez-Morgade, R. K. Pandey, D. K. P. Ng, T. Torres, F. Dumoulin, Chem. Soc. Rev. 2020, 49, 1041-1056; d)F. Heinemann, J. Karges, G. Gasser, Acc. Chem. Res. 2017, 50, 2727-2736.

[2] B. Muz, P. de la Puente, F. Azab, A. K. Azab, Hypoxia 2015, 3, 83-92.

[3] a)C. A. Robertson, D. H. Evans, H. Abrahamse, J. Photochem. Photobiol. B. 2009, 96, 1-8; b)S. Mallidi, S. Anbil, A.-L. Bulin, G. Obaid, M. Ichikawa, T. Hasan, Theranostics 2016, 6, 2458-2487; c)C. Imberti, P. Zhang, H. Huang, P. J. Sadler, Angew. Chem. Int. Ed., 2020, 59, 61-73; d)F. Dumoulin, Photodiagnosis Photodyn. Ther. 2017, 17, A4 - A78.

[4] a)R. M. Sutherland, Science 1988, 240, 177-184; b)P. A. Netti, D. A. Berk, M. A. Swartz, A. J. Grodzinsky, R. K. Jain, Cancer Res. 2000, 60, 2497-2503; c)S. Riffle, R. S. Hegde, J. Exp. Clin. Cancer Res. 2017, 36, 102-112; d)P. J. Dyson, Natl. Sci. Rev. 2019, 6, 1068-1069.

[5] a)L. A. Kunz-Schughart, Cell Biol. Int. 1999, 23, 157-161; b)J. Friedrich, C. Seidel, R. Ebner, L. A. Kunz-Schughart, Nat. Protoc. 2009, 4, 309-324

[6] a)I. Freitas, Tumori J. 1985, 71, 251-259; b)M. Höckel, P. Vaupel, J. Natl. Cancer Inst. 2001, 93, 266-276; c)L. N. Lameijer, D. Ernst, S. L. Hopkins, M. S. Meijer, S. H. C. Askes, S. E. Le Dévédec, S. Bonnet, Angew. Chem. Int. Ed. 2017, 56, 1154911553; d)J. Fong, K. Kasimova, Y. Arenas, P. Kaspler, S. Lazic, A. Mandel, L. Lilge, 
Photochem. Photobiol. Sci. 2015, 14, 2014-2023; e)P. Zhang, P. J. Sadler, Eur. J. Inorg. Chem. 2017, 2017, 1541-1548; f)H. Huang, S. Banerjee, K. Qiu, P. Zhang, O. Blacque, T. Malcomson, M. J. Paterson, G. J. Clarkson, M. Staniforth, V. G. Stavros, G. Gasser, H. Chao, P. J. Sadler, Nat. Chem. 2019, 11, 1041-1048; g)J. Roque III, D. Havrylyuk, P. C. Barrett, T. Sainuddin, J. McCain, K. Colón, W. T. Sparks, E. Bradner, S. Monro, D. Heidary, C. G. Cameron, E. C. Glazer, S. A. McFarland, Photochem. Photobiol. 2019,2, 327-339

[7] A. Raza, S. A. Archer, S. D. Fairbanks, K. L. Smitten, S. W. Botchway, J. A. Thomas, S. MacNeil, J. W. Haycock, J. Am. Chem. Soc. 2020, 142, 4639-4647.

[8] a)D. R. Grimes, C. Kelly, K. Bloch, M. Partridge, J. R. Soc. Interface 2014, 11, 20131124; b)W. R. Wilson, M. P. Hay, Nat. Rev. Cancer 2011, 11, 393-410.

[9] a)H. Huang, B. Yu, P. Zhang, J. Huang, Y. Chen, G. Gasser, L. Ji, H. Chao, Angew. Chem. Int. Ed. 2015, 54, 14049-14052; b)B. S. Howerton, D. K. Heidary, E. C. Glazer, J. Am. Chem. Soc. 2012, 134, 8324-8327; c)V. H. S. van Rixel, V. Ramu, A. B. Auyeung, N. Beztsinna, D. Y. Leger, L. N. Lameijer, S. T. Hilt, S. E. Le Dévédec, T. Yildiz, T. Betancourt, M. B. Gildner, T. W. Hudnall, V. Sol, B. Liagre, A. Kornienko, S. Bonnet, J. Am. Chem. Soc. 2019, 141, 18444-18454.

[10] a)R. Lincoln, L. Kohler, S. Monro, H. Yin, M. Stephenson, R. Zong, A. Chouai, C. Dorsey, R. Hennigar, R. P. Thummel, S. A. McFarland, J. Am. Chem. Soc. 2013, 135, 17161-17175; b)A. M. Palmer, B. Peña, R. B. Sears, O. Chen, M. E. Ojaimi, R. P. Thummel, K. R. Dunbar, C. Turro, Philos. Trans. R. Soc. A 2013, 371, 20120135; c)J. Yellol, S. A. Pérez, A. Buceta, G. Yellol, A. Donaire, P. Szumlas, P. J. Bednarski, G. Makhloufi, C. Janiak, A. Espinosa, J. Ruiz, J. Med. Chem. 2015, 58, 7310-7327; d)F. E. Poynton, S. A. Bright, S. Blasco, D. C. Williams, J. M. Kelly, T. Gunnlaugsson, Chem. Soc. Rev. 2017, 46, 7706-7756; e)A. Li, C. Turro, J. J. Kodanko, Acc. Chem. Res. 2018, 51, 1415-1421; f)R. F. Brissos, P. Clavero, A. Gallen, A. Grabulosa, L. A. Barrios, A. B. Caballero, L. Korrodi-Gregório, R. Pérez-Tomás, G. Muller, V. SotoCerrato, P. Gamez, Inorg. Chem. 2018, 57, 14786-14797; g)J. Shum, P. K.-K. Leung, K. K.-W. Lo, Inorg. Chem. 2019, 58, 2231-2247; h)J. Karges, F. Heinemann, F. Maschietto, M. Patra, O. Blacque, I. Ciofini, B. Spingler, G. Gasser, Biorg. Med. Chem. 2019, 27, 2666-2675; i)S. Monro, K. L. Colón, H. Yin, J. Roque III, P. Konda, S. Gujar, R. P. Thummel, L. Lilge, C. G. Cameron, S. A. McFarland, Chem. Rev. 2019, 119, 797-828; i)M. S. Meijer, S. Bonnet, Inorg. Chem. 2019, 58, 11689-11698; j)P. J. Jarman, F. Noakes, S. Fairbanks, K. Smitten, I. K. Griffiths, H. K. Saeed, J. A. 
Thomas, C. Smythe, J. Am. Chem. Soc. 2019, 141, 2925-2937; k)J. Karges, T. Yempala, M. Tharaud, D. Gibson, G. Gasser, Angew. Chem. 2020, 59, 7069-7075 ; 1)N. Soliman, L. K. McKenzie, J. Karges, E. Bertrand, M. Tharaud, M. Jakubaszek, V. Guérineau, B. Goud, M. Hollenstein, G. Gasser, C. M. Thomas, Chem. Sci. 2020, 11, 2657-2663; m)N. P. Toupin, S. Nadella, S. J. Steinke, C. Turro, J. J. Kodanko, Inorg. Chem. 2020, 59, 3919-3933.

[11] a)P. Kaspler, S. Lazic, S. Forward, Y. Arenas, A. Mandel, L. Lilge, Photochem. Photobiol. Sci. 2016, 15, 481-495; b)V. Novohradsky, A. Rovira, C. Hally, A. Galindo, G. Vigueras, A. Gandioso, M. Svitelova, R. Bresolí-Obach, H. Kostrhunova, L. Markova, J. Kasparkova, S. Nonell, J. Ruiz, V. Brabec, V. Marchán, Angew. Chem. Int. Ed. 2019, 58, 6311-6315; c)J. Karges, O. Blacque, P. Goldner, H. Chao, G. Gasser, Eur. J. Inorg. Chem., 2019, 2019 , 3704-3712; d)D. Havrylyuk, K. Stevens, S. Parkin, E. C. Glazer, Inorg. Chem. 2020, 59, 1006-1013.

[12] a)C. Girardot, G. Lemercier, J. C. Mulatier, J. Chauvin, P. L. Baldeck, C. Andraud, Dalton Trans. 2007, 3421-3426; b)S. C. Boca, M. Four, A. Bonne, B. Van Der Sanden, S. Astilean, P. L. Baldeck, G. Lemercier, Chem. Commun. 2009, 4590-4592; c)J. Liu, Y. Chen, G. Li, P. Zhang, C. Jin, L. Zeng, L. Ji, H. Chao, Biomaterials 2015, 56, 140-153; d)L. Zeng, S. Kuang, G. Li, C. Jin, L. Ji, H. Chao, Chem. Commun. 2017, 53, 1977-1980; e)K. Qiu, J. Wang, C. Song, L. Wang, H. Zhu, H. Huang, J. Huang, H. Wang, L. Ji, H. Chao, ACS Appl. Mater. Interfaces 2017, 9, 18482-18492; f)J. Hess, H. Huang, A. Kaiser, V. Pierroz, O. Blacque, H. Chao, G. Gasser, Chem. Eur. J. 2017, 41, 9888-9896.

[13] a)M. Drobizhev, Y. Stepanenko, Y. Dzenis, A. Karotki, A. Rebane, P. N. Taylor, H. L. Anderson, J. Phys. Chem. B 2005, 109, 7223-7236; b)T. K. Ahn, K. S. Kim, D. Y. Kim, S. B. Noh, N. Aratani, C. Ikeda, A. Osuka, D. Kim, J. Am. Chem. Soc. 2006, 128, 1700-1704; c)M.-C. Yoon, S. B. Noh, A. Tsuda, Y. Nakamura, A. Osuka, D. Kim, J. Am. Chem. Soc. 2007, 129, 10080-10081; d)M. Pawlicki, H. A. Collins, R. G. Denning, H. L. Anderson, Angew. Chem. Int. Ed. 2009, 48, 3244-3266.

[14] J. Karges, S. Kuang, F. Maschietto, O. Blacque, I. Ciofini, H. Chao, G. Gasser, Nat. Commun. 2020, 11, 3262.

[15] a)C. Feuvrie, O. Maury, H. Le Bozec, I. Ledoux, J. P. Morrall, G. T. Dalton, M. Samoc, M. G. Humphrey, J. Phys. Chem. A 2007, 111, 8980-8985; b)M. G. Humphrey, T. Schwich, P. J. West, M. P. Cifuentes, M. Samoc, Comprehensive 
Inorganic Chemistry II (Second Edition) (Eds.: J. Reedijk, K. Poeppelmeier), Elsevier, Amsterdam, 2013, 781-835.

[16] B. P. Sullivan, D. J. Salmon, T. J. Meyer, Inorg. Chem. 1978, 17, 3334-3341.

[17] D. Garcìa-Fresnadillo, Y. Georgiadou, G. Orellana, A. M. Braun, E. Oliveros, Helv. Chim. Acta 1996, 79, 1222-1238.

[18] a)M. J. Cook, A. P. Lewis, G. S. McAuliffe, V. Skarda, A. J. Thomson, J. L. Glasper, D. J. Robbins, J. Chem. Soc., Perkin Trans. 2 1984, 1293-1301; b)V. Balzani, A. Juris, Coord. Chem. Rev. 2001, 211, 97-115.

[19] a)M. D. Hall, K. A. Telma, K.-E. Chang, T. D. Lee, J. P. Madigan, J. R. Lloyd, I. S. Goldlust, J. D. Hoeschele, M. M. Gottesman, Cancer Res. 2014, 74, 3913-3922; b)S. Keller, Y. C. Ong, Y. Lin, K. Cariou, G. Gasser, J. Organomet. Chem. 2019, 121059;

[20] a)U. Basu, J. Karges, F. Chotard, C. Balan, P. Le Gendre, G. Gasser, E. Bodio, R. Malacea Kabbara, Polyhedron 2019, 172, 22-27; b)A. K. Renfrew, J. Karges, R. Scopelliti, F. D. Bobbink, P. Nowak-Sliwinska, G. Gasser, P. Dyson, ChemBioChem 2019, 20, 2876-2882.

[21] a)T. S. Mang, T. J. Dougherty, W. R. Potter, D. G. Boyle, S. Somer, J. Moan, Photochem. Photobiol. 1987, 45, 501-506; b)J. Moan, G. Streckyte, S. Bagdonas, Ø. Bech, K. Berg, Int. J. Cancer 1997, 70, 90-97.

[22] a)J. Karges, U. Basu, O. Blacque, H. Chao, G. Gasser, Angew. Chem. Int. Ed., 2019, 58, 14334-14340; b)J. Karges, O. Blacque, H. Chao, G. Gasser, Inorg. Chem. 2019, $58,12422-12432$.

[23] a)C. Tan, S. Wu, S. Lai, M. Wang, Y. Chen, L. Zhou, Y. Zhu, W. Lian, W. Peng, L. Ji, A. Xu, Dalton Trans. 2011, 40, 8611-8621; b)M. R. Gill, D. Cecchin, M. G. Walker, R. S. Mulla, G. Battaglia, C. Smythe, J. A. Thomas, Chem. Sci. 2013, 4, 4512-4519; c)M. Dickerson, Y. Sun, B. Howerton, E. C. Glazer, Inorg. Chem. 2014, 53, 1037010377; d)H. Audi, D. Azar, F. Mahjoub, S. Farhat, Z. El-Masri, M. El-Sibai, R. J. AbiHabib, R. S. Khnayzer, J. Photochem. Photobiol. A 2018, 351, 59-68; d)J. Karges, F. Heinemann, M. Jakubaszek, F. Maschietto, C. Subecz, M. Dotou, O. Blacque, M. Tharaud, B. Goud, E. V. Zahínos, B. Spingler, I. Ciofini, G. Gasser, J. Am. Chem. Soc. 2020, 142, 6578-6587.

[24] a)V. H. S. van Rixel, B. Siewert, S. L. Hopkins, S. H. C. Askes, A. Busemann, M. A. Siegler, S. Bonnet, Chem. Sci. 2016, 7, 4922-4929; b)D. Kessel, Photochem. Photobiol. 2019, 95, 119-125; c)V. Rapozzi, F. D’Este, L. E. Xodo, J. Porphyr. Phthalocyanines 2019, 23, 410-418; d)C. Donohoe, M. O. Senge, L. G. Arnaut, L. C. 
Gomes-da-Silva, Biochim. Biophys. Acta 2019, 1872, 188308; e)N. M. Vegi, S. Chakrabortty, M. M. Zegota, S. L. Kuan, A. Stumper, V. P. S. Rawat, S. Sieste, C. Buske, S. Rau, T. Weil, M. Feuring-Buske, Sci. Rep. 2020, 10, 371.

[25] J. M. Adams, Genes Dev. 2003, 17, 2481-2495.

[26] a)C. Qian, J.-Q. Wang, C.-L. Song, L.-L. Wang, L.-N. Ji, H. Chao, Metallomics 2013, 5, 844-854; b)H. Huang, P. Zhang, B. Yu, Y. Chen, J. Wang, L. Ji, H. Chao, J. Med. Chem. 2014, 57, 8971-8983.

[27] a)E. A. Thackaberry, Expert Opin. Drug Metab. Toxicol. 2012, 8, 1419-1433; b)B.-Z. Zhu, X.-J. Chao, C.-H. Huang, Y. Li, Chem. Sci. 2016, 7, 4016-4023. 